\title{
Direct Election of Village Head as a Trigger of Corruption Behavior
}

\author{
Mochamad Doddy Syahirul Alam*, Mujibur Rahman Khairul Muluk, Andy Fefta Wijaya \\ Faculty of Administrative Science \\ University of Brawijaya \\ Malang, Indonesia \\ *mahaputra3@student.ub.ac
}

\begin{abstract}
Direct election of village head in Indonesia is a simple form of democracy intended for village people. Many political dynamics occurred before and after the election of the village head. The practice of patron-client that colours the political process that occurs makes the tug of war between the competing camps in contestation increasingly stringent. Kinship seems to be a substantial capital to gain power. Direct election of village head that has a purpose of finding candidates for leaders who are superior and able to advance the village as if not a top priority. This paper seeks to describe how the democratic process in direct village head elections in Indonesia encourages the emergence of corrupt behavior by the village head. This paper will also present various findings that show that elected leaders tend to only pay attention to the interests of the supporters (clients) rather than the interests of village communities in general. It indicates as if the structural change in the regulation governing village governance did not have a significant impact on cultural issues in the village. Data were collected by interview, observation, and documentation as a field study. However, community support groups will in time demand that their elected leaders provide an outpouring of benefits both materially and immaterially. Physically the supporters want the ease of social assistance from the village government. In immaterial supporters want easy access to village administration. It indicates as if the structural change in the regulation governing village governance did not have a significant impact on cultural issues in the village. Data were collected by interview, observation, and documentation as a field study. However, community support groups will in time demand that their elected leaders provide an outpouring of benefits both materially and immaterially. Physically the supporters want the ease of social assistance from the village government. In immaterial supporters want easy access to village administration. It indicates as if the structural change in the regulation governing village governance did not have a significant impact on cultural issues in the village. Data were collected by interview, observation, and documentation as a field study. However, community support groups will in time demand that their elected leaders provide an outpouring of benefits both materially and immaterially. Physically the supporters want the ease of social assistance from the village government. In immaterial supporters want easy access to village administration. community support groups will in time demand that their elected leaders provide an outpouring of benefits both materially and immaterially. Physically the supporters want the
\end{abstract}

ease of social assistance from the village government. In immaterial supporters want easy access to village administration. community support groups will in time demand that their elected leaders provide an outpouring of benefits both materially and immaterially. Physically the supporters want the ease of social assistance from the village government. In immaterial supporters want easy access to village administration.

\section{Keywords—direct election, village head, corruption behavior}

\section{INTRODUCTION}

Village head elections (Pilkades) are a form of democratic practice at the local political level. Since 2014, the Village Head Election in Indonesia has been conducted directly. This is interesting to be a study that continues to be discussed on voter behavior in determining their choices. Every village always has different voter behavior from one village to another. Several factors influence the tendency of voters before deciding who is the right candidate to become a voter, including a convincing personality, clarity of vision and mission, good image, level of education, candidate for village head, religious equality and good candidates [1].

The election of village heads which is carried out directly and simultaneously at the district/city level is aimed at the effectiveness of activities and efficiency of implementation costs incurred by the government and to prevent Pilkades gambling practices in the community [2]. The Village Head is elected directly by and from the Village residents who are citizens of the Republic of Indonesia who meet the requirements with a maximum term of office for 3 (times) consecutive or non-consecutive terms of office. Specifically, regarding the election of the Village Head in this law, it is stipulated that it is carried out simultaneously in all regencies/municipalities to avoid negative things in its implementation [3].

However, it is unfortunate that the Pilkades directly and simultaneously held for the last 6 years or so has not yet achieved the goal, namely Pilkades which is effective and efficient and is free of negative practices. There are still many Pilkades problems found, such as local government 
intervention (district/city), candidate discrimination, gambling, money politics, and vote-buying. As stated by Rudiadi and Herawati [4], regarding the simultaneous election of village heads in the perspective of village autonomy in Rokan Hilir Regency, it is still found that the district government intervenes in the candidacy of the village head by providing additional rules in the form of a condition that "must be able to read the Koran" while for non-Muslim candidates these requirements are not regulated. This case shows that there are still discriminatory practices in the election of village heads by the Rokan Hilir district government. Pilkades gambling cases also still occur in various places, one of which was conveyed by Nurcahyono [5] that in Pohijo Village, Ponorogo Regency, there is a role for Botoh in every Pilkades event. Botoh consists of an individual or group who has an interest in Pilkades. Botoh can be said to be a local strongman capable of regulating and influencing the Pilkades process and outcome. The involvement of Botoh had a bad impact on the effectiveness of the Pilkades administration. Botoh will use money as a political tool to win over one of the candidates by giving pocket money to choose one of the candidates supported by Botoh, this is a practice of money politics.

Aspinall and Rohman [6] in his study said that the election of village heads in two villages in Central Java was mostly controlled by people who had more economic power, this economic power was used to make vote-buying so that what appears is the continuity of the power of the village elite in controlling the head election. village. This raises the perception that only the rich elite are capable of getting the position of village head.

This study aims to describe how the process of local political democracy indirect and simultaneous village head elections can lead to corrupt behavior by village heads. This research is based on the perspective of state administration, especially in terms of implementing clean and authoritative governance, or we often call it good governance [7].

We have to be very concerned about the various efforts to prevent and prosecute corrupt practices, including the unclean and unauthorized implementation of Pilkades. Corruption will increase the inequality between rich and poor, between leaders and followers, between rulers and society. The corruption that colours every area of socio-political and economic life will not be able to prosper the society at large. Corruption will only lead to instability in political and economic life [8].

When corrupt practices are allowed to run rampant in every institution, jurisdiction, social and economy, a greater impact will be felt by society in particular and economic development in general. Efforts to prevent corrupt practices can be supported by various aspects including economics, psychology and criminology [9]. Two main aspects cause corruption, namely bad policies and non-transparent budget implementation, both of which neglect the various needs of society. Corruption occurs when the system is not sufficiently transparent to the public. Decentralization and corruption are now interrelated which threaten the quality of democracy and public accountability [10].

The direct and simultaneous election of the Village Head has very good benefits in democracy and political decentralization in the village. As stated by Raharusun [11]. First, direct election of village heads encourages the strengthening of democracy at the local level, particularly the development of political legitimacy. Second, the direct election of village heads is expected to be able to build and realize village accountability and strengthen democratic values in the Indonesian constitutional system.

This paper is expected to be able to present the latest issues related to the holding of village head elections which are still ongoing without any good solution from the government and the community. In addition, it is hoped that they will be able to recommend practical solutions for the prevention and eradication of negative practices in village head elections in Indonesia which lead to corrupt practices in the administration of village governance.

\section{LITERATURE REVIEW}

\section{A. The Village between Patronage and Political Charisma}

There is a quote from Warren Buffet written in McCulloch's book [12] "There is class warfare, all right. But it is my class, the rich class, that is making war, and we're winning ". This is a statement that represents the condition of the political constellation when the Pilkades was held. Every village elite in this regard is a rich person who feels that the competitive map only involves the rich in the village. Apart from that, it will not be considered as a force capable of advancing to compete in the Pilkades contest.

Capitalism often supports the implementation of a good and quality democracy. But capitalism is more often than not a poison to inclusive democratic politics, leading to rampant inequality [12]. So far, the implementation of village head elections in Indonesia has been more influenced by the capital strength of the village elite in exercising their hegemony of power at the village level.

Patronage in its original and non-original forms is socially transitive and can erode the idea of self-ownership, including the right to joint membership. Patronage often results in reliance on binding hierarchical obligations. This obligation becomes mandatory for binding agreements, which implies that the social order is legally considered or accepted [12]. This situation is what happened in village-level political contestation.

\section{B. Kinds of Corruption in the Village}

Talking about corruption at the village level, in principle, is not different from corrupt practices at the district/city, provincial and central government levels. These corrupt practices exist and appear in the public sector [13]. Some of the smallest types of corruption in the public sector include pay- 
related fraud, travel and allowances, exploiting assets and information, procurement fraud, theft assets and information, and management-related fraud personnel (figure 1).

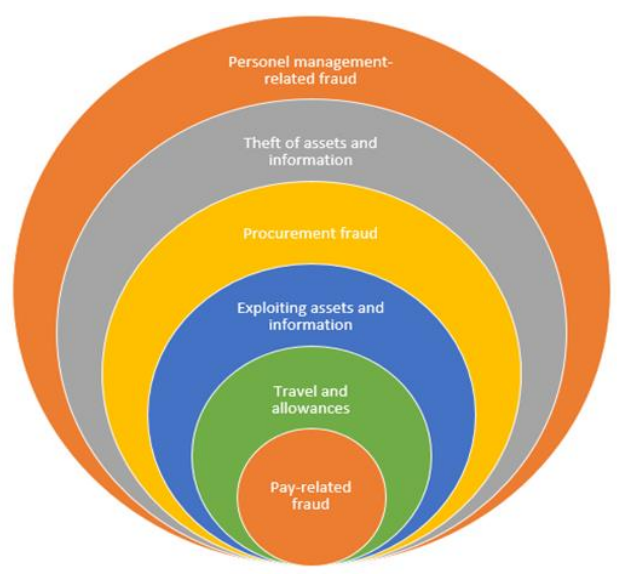

Fig. 1. Type of public sector corruption Her Majesty's Treasury.

\section{Privileges of a Village}

There is a village saying that says "Desa Mawa Cara, Negara Mawa Tata". This proverb also emphasizes the multiculturalism that exists in every village, this is reinforced by another adage, "where the earth is stepped, there the sky is upheld". The way Mawa village is interpreted as a village has its way in the social life of its people, all of which are manifested in customs, habits, local wisdom, and local initiatives. Meanwhile, the state is defined as the state has a way of regulating the life of rural communities through regulations, law, administration, bureaucracy, planning, finance, accounting, and so on. Thus, these two matters between the village of mawa cara and the state of mawa tata should proceed in harmony, harmony, and balance by promoting social justice for all Indonesian people. However, what happens is often not the case. The state tends to be more dominant politically over rural communities. Village government is often used as a tool for the state to impose the political will/appetite of the ruler on a village. Meanwhile, villages tend to be more culturally dominant towards the desire of the State to regulate the village in economic terms. What happens is that these programs are stalled in the middle of the road or are unable to sustainably increase village progress. Sutoro Eko referred to this feature as the concept of "Small Country" to understand the meaning and position of the village. Meanwhile, villages tend to be more culturally dominant towards the desire of the State to regulate the village in economic terms. What happens is that these programs are stalled in the middle of the road or are unable to sustainably increase village progress. Sutoro Eko referred to this feature as the concept of "Small Country" to understand the meaning and position of the village. Meanwhile, villages tend to be more culturally dominant towards the desire of the State to regulate the village in economic terms. What happens is that these programs are stalled in the middle of the road or are unable to sustainably increase village progress. Sutoro Eko referred to this feature as the concept of "Small Country" to understand the meaning and position of the village [14].

\section{METHODS}

This research is a field study which took place in Ngawi Regency, East Java, Indonesia. By taking two sites, namely Baderan Village and Widodaren Village. The two villages held Pilkades simultaneously on June 29, 2019. The two villages were deliberately chosen by researchers because of their uniqueness where the elected Head of Baderan Village was a former village head in the previous period who was convicted of a corruption case. Meanwhile, Widodaren Village is unique because the elected village head always has a close kinship with former village heads. Likewise, the village head was elected in 2019.

Primary data were obtained from interviews with village officials and community leaders as well as field observations. Meanwhile, secondary data were obtained from documentation and online literature studies.

The approach used in this research is an intrinsic case study approach with qualitative methods. The data are processed and analysed with the support of the NVIVO 12 Plus data management application.

\section{RESULTS AND DISCUSSION}

\section{A. Money Politics}

As expressed by one community leader (Sro) in Baderan Village, "Now in Pilkades 2019 everyone has an allowance of around IDR. 200,000 - 250,000 without adding a bandul worth IDR. 200,000 ". The 200,000 / person pocket money referred to is the pocket money offered by one of the village head candidates to the Baderan Village community before the voting time. The allowance is used as a lure for the public to attend and vote for candidates. There are even candidates for village heads who dare to give additional money which is termed "bandul" worth IDR. 200,000 per person if the candidate is declared victorious. The researcher then visited Sro's residence at around 9 am on June 29, 2019.

The community leader (Sro) conveyed information to the researcher in a calm voice without any burden. This seems to be commonplace when there is a Pilkades event, the candidates then promise pocket money and bandul to the public. It could be that this is considered a democratic party at the village level, where people enjoy money politics circulating in the community ahead of the village head election.

Until the evening around 9 o'clock when researchers conducted field observations around Baderan Village, there was still no sound or visible movement of giving out pocket money as conveyed by the community leader. What was seen at that time in the house of one of the candidates who was later declared the winner there was a group of people clustered as if they were discussing or discussing something seriously, quite a lot of more than 10 people. Researchers did not see directly 
that money was distributed to the public at that time. This has become a limitation for researchers because before 10 o'clock all the people outside the villagers of Baderan were asked to leave and then there was an area limitation in the form of a village portal that closed access to and from Baderan Village.

We can predict that the movement to distribute money to the community by the success team of village head candidates is likely to be carried out from $10 \mathrm{pm}$ until the morning before the voting. This was very possible because at that time Baderan Village had been sterilized from residents outside the village so that only indigenous villagers and security forces (Police and Linmas) were left. Police and Linmas do not have the authority to act against prospective village heads who distribute pocket money to prospective voters.

Pilkades in Baderan Village can be a clear example of how political life in the village is currently thick with patronage and political charisma. Where the political charisma is one of which is measured by the size of the material provided by the Village Head candidate to the community. The emergence of "pocket money and bandul" ahead of Pilkades is considered a natural thing for the community, it strengthens McCulloch's thinking [12] that the power of capital is often used as a support for the democratic process and at the same time a poison for democracy itself.

A different situation occurred in Widodaren Village, were approaching the day of the Pilkades implementation, the village head candidates still had not shown a serious movement who would run for themselves and whether or not pocket money and bandul were needed when running for Pilkades.

One of the community leaders (BS) who is also the former head of Widodaren Village for the 2009-2014 period said: "now to run for village head requires at least 350 million for the operational needs of the success team and pocket money to the community". Incidentally, this period he was not interested in running and contributed more thoughts to other candidates who needed his support. When did the researcher ask whether that amount of money must be available, can't it be without money but rather the participation of the supporting community? He replied, "This is very unlikely to happen. We cannot expect society to support us materially., with the Pilkades, people are accustomed to waiting for pocket money from village head candidates ". Through him, the researcher got information that the value of the pocket money in Widodaren Village was IDR. 150,000-200,000 per person. In Widodaren Village, there are no candidates who offer a "bandul". What did exist was an offer from one of the candidates to give up part of his private rice field as land that could be cultivated by his supporters. Unfortunately, the village head candidate who submitted this bid lost the Village Head Election in 2019.

While those who won were other candidates who were younger (Bs) and were not heard of using pocket money in Pilkades. This is reasonable because the elected candidate is the son of one of the former members of the Ngawi Regency Regional Representative Council (DPRD) from the Indonesian
Democratic Party of Struggle (PDI-P) who happened to be in the 2019 Legislative Election not being elected as a DPRD Member. It is an interesting study on how this candidate for village head was able to win the Widodaren Pilkades without using money.

The Pilkades in Widodaren Village provides another fact regarding the power of patronage and political charisma, where the patronage that appears is not from Widodaren Village but the power of the Regent of Ngawi. With the power of the Ngawi Regent plugging in politically in Widodaren Village, this will encourage the dependence of the elected Village Head on the Ngawi Regent. Which indirectly will hinder the independence of the village. The mindset of the Widodaren Village Head will be supported by the power of the Ngawi Regent. So that the village's creativity and innovation to build is very lacking. This will encourage various forms of corruption in the public sector [13].

\section{B. Conflict of Interest in Village Head Direct Election}

The election of the Village Head in Ngawi Regency is very thick with political conflicts of interest with the Ngawi Regency Government, in this case, the Regent who was heard directly by a researcher from one of the State Civil Servants (Ko) who served in the Ngawi Regency Government and settled in Widodaren Village.

The Widodaren Pilkades will likely have the role of the Regent of Ngawi to win one of the village head candidates. Although there was no political support found as evidence of support from the Regent, political support was in the form of a strong appeal to the people of Widodaren Village to elect one of the village head candidates who was the son of a former member of the Ngawi Regency DPRD from PDI-P. Ko said, "I had a chance to meet the Regent and was asked to sit quietly and support what the Regent wanted, not to be opposite or want to change assignments farther from his current assignment". Ko delivered the statement in a calm tone but there was an expression that he felt pressured by his boss, so he did not continue the conversation. The intervention of the Regent was not easily proven by the general public.

If we look at the case study in Widodaren Village, two possibilities will happen if Bs as the winner of the Pilkades will become a leader who can protect the community well and can bridge the interests of the village and the interests of the state, in this case including the interests of the Regent of Ngawi [15]. Another negative possibility is that if the selected BS is not able to carry out the community's mandate, then BS will simply become an intermediary to strengthen or dominate the interests of the state and the authorities towards the village community.

The Baderan Pilkades also cannot be separated from the conflict of interests of officials in Ngawi Regency, in this case, one of the top officials at the Ngawi District Prosecutor's Office. Of the 4 (four) village head candidates who competed in the Baderan Pilkades 2 of them ( $\mathrm{Si}$ and $\mathrm{So}$ ) were relatives of high-ranking officials of the State Prosecutor's Office who happened to be originally born in Baderan Village. In 2017 the 
support from these officials did not succeed in making $\mathrm{Si}$ the Village Head. Because at that time So sued that he be allowed to participate in the Pilkades contest. So, benefit from the Decision of the Surabaya State Administrative Court (PTUN) Number: 109 / B / PT.TUN.SBY Year 2018 which postponed the 2017 Baderan Pilkades stage.

Considering the phenomenon that occurs in Baderan Village where there is a link between village officials and highranking officials at the Ngawi State Prosecutor's Office, shows that currently the relationship between village officials and other powers outside the village is needed to strengthen political power or to be used in other agendas. The relationship between the village elite and state power has changed considerably [6]. Village elites not only need state apparatus, but these officials also need partners in the village to gain power and patronage. In this case, the ability of village elites to establish relationships with the authorities is very much needed, there is flexibility and ability to adapt to developing situations and conditions, this shows that state connections are more important to village elites than just showing loyalty. Agreement-making and intermediaries are keys to political success in rural patronage democracy in Indonesia [6].

The issue of preventing corruption in local politics does not depend on dynastic or non-dynastic leadership. There will always be opportunities for a tug of war between leaders and supporters in every direct regional head election. This includes the election of the village head. The most important thing in efforts to prevent corruption that must be done is to strengthen government control. Five things can be done to prevent corrupt practices in the regions, including supervision in political recruitment, one of which is the Pilkades, bureaucratic neutrality, transparency and accountability in budgeting, as well as oversight of regional policies to avoid pork tong policies [16]. It is homework for the government to design a kind of Election Supervisory Body (Bawaslu) at the village level that can prevent negative Pilkades practices.

This opinion was reinforced by Prabowo and Cooper [17] that efforts to prevent and eradicate corruption in public institutions in Indonesia must at least implement three pillars, namely institutionalization, rationalization and outreach. The three pillars are expected to strengthen each other to strengthen the anti-corruption normalization structure to be very strong. Corruption will completely disappear from Indonesia only if it is carried out with social schemes, organizations, and individuals to realize that corrupt habits or behavior are no longer a tradition or norm that is considered normal. So, it is necessary to normalize the behavior of the corrupt state apparatus.

\section{CONCLUSION}

Based on the results of the above research, as the phenomenon that occurred in Baderan Village and Widodaren Village, we can understand together that it turns out that at any level the regional head general election is held will encourage corruption practices. The practice of corruption occurs in 2 phases, namely the phase before direct elections is held, and the phase after the elected candidate is declared the winner and holds power. This phenomenon naturally occurs because the process of supporting support in general elections and Pilkades is carried out on a transactional basis, not based on rational political decisions.

What should be done is that the government must be able to establish a supervisory system in the implementation of Pilkades that can break through cultural barriers that are often encountered at the village level. Concretely, it is the formation of Bawaslu at the village level. It would be futile if the fight against corruption was only carried out at the central and district/city levels but ignoring corrupt practices at the village level in the form of abuse of power.

This research is still far from perfect in presenting authentic field data related to actors who play a role in village head elections. This is due to the limitations of researchers in extracting the required data. It is possible to carry out further research in more depth, one of which is the ethnographic approach.

\section{ACKNOWLEDGMENTS}

This research is held in a series of research dissertations in the Doctoral Program of Administrative Sciences Universitas Brawijaya. Thanks are conveyed to the Education Fund Management Institute (LPDP) of the Ministry of Finance of the Republic of Indonesia for facilitating research budget support, as well as the promoters and co-promoters of researchers who always provide directions so that research and publications can be completed properly.

\section{REFERENCES}

[1] R.M. Amin and K.K. Astuti, Study Perilaku Pemilih dalam Pemilihan Kepala Desa (Pilkades) di Desa Dayun Kecamatan Dayun Kabupaten Siak Periode 2013-2019 (Doctoral dissertation, Riau University).

[2] A. Imam and S. Ma'mun, "Evaluasi Efektivitas Pelaksanaan Pemilihan Kepala Desa (Pilkades) Serentak Di Kabupaten Pamekasan Tahun 2015," Aspirasi: jurnal ilmiah administrasi negara, vol. 2, no. (1), pp. 25-34, 2017.

[3] Law of the Republic of Indonesia Number 6 of 2014 concerning Villages.

[4] R. Rudiadi and R. Herawati, "Pemilihan Kepala Desa Serentak Dalam Perspektif Otonomi Desa (Studi Kasus Pelaksanaan Pemilihan Kepala Desa Serentak Tahun 2016 di Kabupaten Rokan Hilir, Provinsi Riau),' Law Reform, vol. 13, no. (1), pp. 132-151, 2017.

[5] T. Nurcahyono, Dampak Keterlibatan Botoh Pada Implementasi Pilkades Di Ponorogo Studi di Desa Pohijo, Kecamatan Sampung, Kabupaten Ponorogo Provinsi Jawa Timur (Doctoral dissertation, Universitas Muhammadiyah Ponorogo), 2016.

[6] E. Aspinall and N. Rohman, "Village head elections in Java: Money politics and brokerage in the remaking of Indonesia's rural elite," Journal of Southeast Asian Studies, vol. 48, no. (1), pp. 31-52, 2017.

[7] R.S. Zuhro, "Good Governance dan Reformasi Birokrasi di Indonesia," Jurnal Penelitian Politik, vol. 7, no. (1), pp. 21, 2016

[8] J.E.M. Shariha, B. Supriyono, A.F. Wijaya and S. Zauhar, "Corruption in the regime's apparatus and state institutions in Libya during Gadhafi's 
rule, International Refereed Journal of Engineering and Science (IRJES), vol. 3, no. (11), pp. 01-03, 2014.

[9] E. Dimant, "The Nature of Corruption: An Interdisciplinary Perspective. Economics Discussion Papers,“ Kiel Inst. World Econ., vol. 17, no. 59, pp. 53-72, 2013.

[10] M.Z. Mohamed, A. Martadha, A. Ismail, N. Syakiran and A. Bakar, "Journal of New Government Paradigm," vol. 1, pp. 1-15, 2014.

[11] A. Raharusun, "Local Election and Reinforcement Democracy in the Indonesian State System," Papua Law Journal, vol. 2, no. (1), pp. 1-25, 2017

[12] A.D. McCulloch, Charisma and Patronage: Reasoning with Max Weber, First. Wey Court East: Ashgate Publishing Limited, 2014.
[13] J.E. Campos and S. Pradhan, The many faces of corruption: tracking vulnerabilities at the sector level. World Bank Publications, 2007.

[14] S. Eko, T.I. Khasanah, D. Widuri, S. Handayani and N. Handayani, Desa membangun indonesia. Yogyakarta: FPPD, 2014.

[15] H. Antlov, H. Antlöv and S. Cederroth, Leadership on Java: Gentle hints, authoritarian rule (Vol. 16). Psychology Press, 1994.

[16] T. Purwaningsih and B.E.C. Widodo, "The Interplay of Incumbency, Political Dynasty and Corruption in Indonesia: Are Political Dynasties the Cause of Corruption in Indonesia?" Revista UNISCI, vol. 53, 2020.

[17] H.Y. Prabowo and K. Cooper, "Re-understanding corruption in the Indonesian public sector through three behavioral lenses," J. Financ. Crime, vol. 23, no. 4, pp. 1028-1062, 2016. 